\section{Philosophical And Cultural Analysis Of The Basic Concepts Of Modern Bioethics}

\author{
Isaxova Shaxlo Mukhtorovna, \\ Basic Doctoral Student (PhD), \\ National University, Uzbekistan
}

\author{
G open ACCESS \\ The American Journal of \\ Social Science And \\ Education Innovations \\ JULY 2020 \\ Page No.: 224-231 \\ Volume-II Issue-VII \\ PUBLISHED: 30 JULY 2020 \\ www.usajournalshub.com/inde \\ x.php/tajssei \\ Copyright: Original content \\ from this work may be used \\ under the terms of the \\ Creative Commons Attribution \\ 4.0 licence.
}

\begin{abstract}
This article deals with the basic concepts of bioethics and the ethical issues of euthanasia and cloning. The word euthanasia today means making certain efforts to find a good death. That is to take any positive or negative action to find that good death One of the most problematic cases of Bioetka today is the process of cloning. In connection with cloning, i.e. the cultivation of a complete copy of an organism's somatic cells, the results of altering the criminal nature of man using hereditary engineering methods depend on the ethical system prevailing in the relevant culture adopted by the researcher.
\end{abstract}

Keywords: Science development, euthanasia, cloning, bioethics, human life, biotechnology.

\title{
Introduction
}

At the current stage of scientific and technological development, the strict medical control of human mortality further increases the urgency of this problem. It is known that there is a growing debate on the issue of euthanasia, is painless death. The role of philosophers, as well as representatives of the field of bioethics, in the study of these problematic issues is invaluable. Because the eternal problem of philosophy is also related to man and his life. That is why most philosophers saw eternity as the good that people do to people and this make a good name for themselves. At the same time, there is still a lot of debate among physicians, lawyers, sociologists and psychologists about the attitude of deliberately accelerating the death of a terminally ill patient in order to save him from suffering. The English philosopher Francis Bacon (1561-1626) coined 
the term " euthanasia " (Greek " euthanasia" "eu" - good, "thanatos" - death) to describe a mild painless death, ie a good easy and light death without suffering. However, it should be noted that today it is given a more complex meaning. The word euthanasia today means to make a certain effort to find a good death. That is, to do something positive or negative in order to find that good death. "[1. Tishchnko P, D -P.35 ]

\section{The Main Findings And Results}

The problem of the former USSR eftanaziya among the general public almost never been discussed but not always cause debate among experts eftanaziyaga been required to allow movement of the US at the 1935 S.K Millard "Eftanaziya " after striking a society. In this regard, Z. Mukhammedova: "Euthanasia - (finding a good death) " as a new way to solve the problem of medicine is entering modern health practice under the influence of two main factors. First, the development of medicine, including the development of resuscitation, which allows the prevention of patient death, that is, working in a deathcontrol mode. Second, in modern civilization, changes in values and moral priorities are the result of the idea of human rights coming to the fore. There are also changes in the professional consciousness and values of health workers, who, on the one hand, are stranded on the border of life and death, and on the other. involved in social processes. The problem of euthanasia arises today and suddenly, no its roots go back to the value. The problem of the twentieth century, 60 years eftanaziya the public in a completely different point of view ko'tarildi.70 years - Delfte city ( the Netherlands, a Catholic hospital oncology department of anesthesiology physician P. Admiral: ) "Eftanaziya treatment can be carried out after the process ", he called. According to his prediction: Eftanaziyani man's natural right to be recognized as giving us our next generation will understand . " [2 Mukhamedova Z.M.

He was the first to make an open assessment of the status of euthanasia use in the Netherlands, indicating that up to 3,000 cases of euthanasia occur each year in $0.02 \%$ of cases (15 million people in the country). Euthanasia is characterized by extreme contrast. This makes it difficult to interpret the term in the same way and leads to terminological confusion. Depending on the definition of the term, the approach to the problem of euthanasia also changes. Passive and active euthanasia (also known as the "excluded syringe method") is characterized by the cessation of life-prolonging medical care, which accelerates medical death. In addition, the "right eftanaziya "," forced euthanasia ", " curved eftanaziya " , "voluntary eftanaziya " s. Eftanaziya often referred to eftanaziya tutiladi.Faol eftanaziya (it is " filled shchprits method " method is also called) will cause a quick and painless death, dying of any medication or other means will be allocated through Pritt or other similar actions are understood.

So the essence of the problem of active euthanasia is that the doctor takes pity on the patient or kills him at the request of the dying person, his relatives. Such active euthanasia is strongly condemned not only in our country, but also in other countries. Many doctors and lawyers abroad believe that it is absolutely criminal, even if it is done out of "compassion " or at the request of a patient who is about to die. In the Netherlands, for example, euthanasia is punishable by up to twelve years in prison if the doctor, in consultation with other physicians who have obtained the patient's consent, proves that the patient is terminally ill and suffering severely. But after lengthy 
discussions in the Netherlands, it was decided to allow passive euthanasia by law. This meant, of course, that no abuse would be tolerated. In England, on the other hand, after a long debate, a law was passed banning any euthanasia in medical practice. At the same time, in many countries, euthanasia is used to some extent under the pretext of ensuring human rights, even in violation of existing norms of law. All this creates great difficulties in the legal assessment of the right to a dignified death. However, in some countries this right is enshrined in law. For example, according to the legislation of the state of Indiana (USA), the situation in which a person is alive is encouraged. In this case, the client often a life of its own artificial uzaytirmaslikni officially tastiqladi.1977yilda California (USA) After a long discussion at the referendum, the first in the world " human right " in accordance with the law, were suffering from chronic ailments, the document expressed a desire to put off the apparatus of intensive care patients In many countries, despite the differences of opinion, passive euthanasia is being formalized by public opinion, and in some countries by the rule of law. For example. In Sweden and Finland the law of passive euthanasia is not contradicted by the cessation of life support in vain. But the free and conscious will of the patient is required for the physician to decide whether to discontinue treatment.Today, euthanasia is practiced everywhere whether it is permitted by law or not. According to the American Medical Association, 6,000 people die every day in U.S. hospitals. Most of them die voluntarily with the help of medical personnel. In the intensive care unit of San Francisco Hospital, 5\% of patients died as a result of disconnection from the life support system. It is noteworthy that this decision was made by the doctor in consultation with the patient's family. However, the patient's informed consent based on awareness is a universally accepted mandatory condition of euthanasia. According to the literature, $40 \%$ of all actions involving patient death occur as a result of physicians' decision to terminate life or by refusing treatment or using death-accelerating drugs. [3. Arokov V.I.- P. 208]

Despite the adoption of a law banning euthanasia, its use is increasing. This is acknowledged by doctors themselves. For example, Mike Torvin, a former United Nations medical director and an American physician, admits that he helped 50 of his patients die. In the Netherlands, euthanasia has long been banned by law. However, in 1996, the Supreme Court and parliament approved the April 14, 1994 directive, which sets out a list of circumstances in which a physician may contribute to suicide by prescribing an injection or oral administration of the drug. After years of debate and discussion in the press, on November 29, 2000, euthanasia was legalized on many terms. In this sense, Z. Muhammedova "According to some scholars, the legal regulation of euthanasia is beyond the medical point of view, and from the point of view of psychologically dangerous ethics contradicts the principles of incorrect medicine. " [4 Muhammedova .Z.-P. 811 writes. For example, in the current CIS countries, all forms of euthanasia are prohibited by law. A person who deliberately incites a patient to euthanasia is criminally liable under the law. However, this does not solve the problem. When talking about hopeless patients suffering from severe pain, the question arises before the physician as to whether it is appropriate to continue to support the patient's life and thus subject him to physical suffering or to end such a life. Naturally, this country must be resolved from a moral and ethical point of view, as well as given a legal assessment. In MDX countries, there is no tradition of informing the patient about the state of their health. It is usually 
sufficient to provide complete information to the patient's relatives. Now, with the adoption of new laws and regulations, this situation should change to some extent. Because according to them, every citizen has the right to receive full information about the state of their health. The urgency of the issue of euthanasia today can be justified by the following. The relevance of the issue of euthanasia today can be justified by the following: First, euthanasia has methodological significance, as it covers anthropological problems related to human life and its existence. [5 Fut.F. -P.62-80]

In this sense, the role of euthanasia in solving these problems, the need to determine the philosophical nature of the objective and subjective factors that affect it, also determines the importance of this topic. Second, the debate over the active and passive manifestations of euthanasia is currently being seriously analyzed by social and humanitarian professionals and physicians. According to him, a one-sided approach in the study of euthanasia does not give the expected result. To do this, all representatives of the field must come to a clear conclusion in cooperation. Because the importance of life for man is one of the main problems not only of philosophy, but also of science in general. Many scientists have offered their constructive basis, which recommended that the conclusions of the note.[6. Reychels DJ.-P.205-211]

Third, current scientists are more confident in the possibilities of passive euthanasia.[7. Potter.B.-P.42] In passive euthanasia, the doctor stops fighting for the life of the patient with chronic pain. But no action is taken to hasten his death. According to him, it is extremely important to take measures to maintain and prolong the life of the patient for some time using euthanasia. Important aspects of human existence are reflected. That is why existential issues concerning the meaningful and meaningless course of human life have been solved in a unique way. Fifth, euthanasia encompasses problems that have an epistemological basis, because philosophers' desire to know death has developed over a long historical period. There are different paradigm views on the issue, and it is important to study their enumerated aspects. But bioethics today pays special attention to the ethical aspects of the doctor-patient relationship, including euthanasia and death detection, human organ transplantation, abortion, cloning, and genetic engineering. In this regard, N. Shermuhamedova said: "In the process of responding to the current problems of our time, modern philosophy of science has encountered a number of complex phenomena. The phenomenon of passion, which is of great interest to us, the phenomenon of virtual reality, which is popular today. The cloning process is one of those complex events. "[8 Shermuhamedova N.A-P.195].

From the above discussions, we are convinced that there is a necessity of death from man. This can be based on optimism or pessimism. In other words, human life is directly related to the spiritual realism of human medicine, the main task of modern medicine is to create favorable conditions for the prevention of disease, disability and death of patients. should consist of a high level of quality service to each person based on his or her genotype. However, there are problems in this area in our country. For example, the negligence and irresponsibility of our doctors often causes people to die prematurely.

Another problematic case of bioethics today is the cloning process. In connection with cloning, i.e. the cultivation of a complete copy of an organism's somatic cells, the results of altering the criminal nature of man using hereditary engineering methods 
depend on the ethical system prevailing in the relevant culture adopted by the researcher. The advances in genetic engineering that have now made it possible to clone human beings have created a range of new ethical challenges. Let us first consider the moral system of Buddhism, which consists of the following ten beliefs. Kill a living creature, a sin not to lie, steal, to drink not to eat, not to escape, of pleasures, jewelry Garden and the use of perfume, cosmetics, luxury living in the house, not to spend in gold and silver. In other words, in the Buddhist moral system, as in other moral norms of the East, a negative attitude towards the selfish aspects of man is accepted. Cloning allows the creation of theoretically homogeneous genetic code people with the same qualities and tendencies. But before science can clone human beings, ethics experts want to ask and answer a number of complex questions. Expressed their intention to discuss the complex issues arising in connection with the research. But scientists have strongly criticized this aspiration of bioethics experts, accusing them of cowardice and panic. Human cloning cannot serve any specific scientific purpose. At a time when the idea of human cloning is on the verge of being realized, society as a whole is in a morally awkward position. Understanding the possible consequences of human cloning has led to different approaches among ethics experts. Some see cloning as an inappropriate interference with human nature, some measure the morality of this or that action by the motives behind it, and some worry that such actions will have largely negative consequences for both society and people.

Some ethics experts argue that exceptions should be made to the rules prohibiting cloning. M. If a tender person is opposed to human cloning, but wants to have a male heir to continue the seed at a time when someone's offspring is doomed to extinction due to infertility, the scientist would have advised him to perform the cloning operation only negatively rather than using donor sperm. Boston College ethics specialist L.S. Cahill is less convinced that cloning is a feature.[9. Wood KL Today the sheep.-P.48] He doubts the mother of twins, the egg cell Cahill cloning inevitably either clones or copies of the original value - the value of discrimination in doubt. After all, in essence, both twins and clones are genetic copies - ku. However, the problem of genetic modification and the consequent human transformation, like other ethics experts, is of great concern to Cahill. Moreover, it is important to keep in mind the commercial aspect that human cloning is a priority in Western civilization. What could stop a wealthy buyer who wants to have a very beautiful, intelligent, or gifted child from buying DNA, even in "small amounts"?

In addition to the debates of experts and national religious communities, a nationwide approach to the problem of cloning also plays an important role. All theologians agree that a clone will have a human-like spirit. Although the pope has not yet addressed the problem of human cloning, the Vatican has repeatedly condemned the use of human embryos for purposes unrelated to treatment. Islamic courts have also not yet ruled on the issue of cloning, but Muslim scholar Abdulaziz Saheddin, a medical ethics specialist at the University of Virginia, said he was deeply concerned about the future consequences of human interference in reproduction. "Imagine a world without the need to establish a marriage ", he said. A. Verey, a Protestant ethicist at Hawyne College in the Netherlands, warns that cloning forces parents to treat children as products. Buddhist scholar D. Lopez pointed out that human cloning raises the problem of karma 
theory. " Does the karma of the original drug become a clone ?" raised the question. However, according to research conducted by American scientists and their results, it seems that American society is moving in the direction of silently approving cloning. "There are two qadryat in the society, they are one generation leave any opportunity to work in the field ", says an American expert on ethics D. Kalaxen. [10 Wood ward KL Todat the sheep.-P.48]

Oh the problem of lack of cloning keep in mind that in Russia there are different approaches to science. "Bulletin of the Russian Academy of Sciences " magazine columnist Ya.T. Rokityansky is the director of the Institute of Bioorganic Chemistry of the Russian Academy of Sciences, academician V.T. In an interview with Ivanov asked him: " the biggest animal cloning experiments carried out on the new technology is causing a sensation: cloning a man of great importance for agriculture, opportunities, and in this regard mention the moral and ethical problems occur. I wanted to know what you think about it . "[11. Bulletin of the Academy of Rossiyskoy Nauka.-P 295 ]

It is no coincidence that a well-known expert in the field of bioorganic chemistry was approached with this question, as chemists today are synthesizing simple proteins and much larger parts of DNA, including genes and genols that control various parts. In other words, the two basic elements of life are chemically (with the element, which can be synthesized by the way) that saw that in the future it is possible to create microorganisms first. Biologists are able to create living organisms that do not exist in nature by interfering with the genetic apparatus and artificially obtaining genetic material. In this sense, the answer of VT Ivanov, one of the leading experts in the field of chemistry and biology, is noteworthy: "As far as I know, I am a chemist, but I follow with great interest the areas of biology where cloning of living organisms. It should be borne in mind that the cloning of higher organisms is not the artificial creation of a living being, but the creation of similar ones in other ways in nature. "Dloning organisms based on DNA from a somatic cell, not a current germ cell, is very popular . "[12 Essay Journal.-P 39]

This has been proven by experiments on both aquatic and terrestrial animals. First, no noise - there was no unrest. Experiments on mammals began, and the issue of human cloning began after it was put on the agenda. But there are still a lot of incomprehensible things and technical difficulties. For example, although DNA is biodifferent in all cells, inevitable changes have taken place in the asexual cell with age. Therefore, it is still unknown how cloning using " adult " genetic material will work. In the meantime, wouldn't a child be born who is naughty, who doesn't have good abilities ? It is not possible to conduct such an experiment until all the issues have been thoroughly investigated. This is a matter of safety and ethics. The academic suspicion turned out to be true. According to media reports, signs of premature aging have been reported in a sheep nicknamed Dolly, created by the cloning method. In biology, however, there is a principle that the processes in the animal body are specific to the human body. Therefore, the problem of human cloning has not faced an unexpectedly serious challenge, even in the field of biology. Interference with human physical nature by hereditary engineering methods, including solutions to cloning problems, is determined by the division of existing ethical systems into two groups. The first group includes ethical systems that consider a particular act as a criterion for spiritual evaluation. At the same time, ethical systems are aimed at committing actions that can be assessed as at least not 
contrary to ethical principles. Beloging to thesekond group,ethikal systems focus on the behavior of the subjekt in accordance with the moral prinsiples, that is, he ptioritizes his moral condition, his intetions, rather than the actions of the subjekt. "It has become a new era for a subject to draw conclusions about his spirituality based on his actions and not on his inner state. The good qualities of the ethical systems of the ancient and medieval times were more eager to determine the ways of becoming a real human being. The moral systems of the new age, freed from the influence of religion, emphasize the identification of the spiritual qualities of the deeds committed, not of man. But this leads to the notion that spirituality loses its relevance, while the moral system seeks to describe and justify false ideas that have nothing to do with life. "[13 Shrayder.Yu.A. -P 244-2481

Scientists point out that cloning humans in unlimited quantities is dangerous. For example. Stanford University Professor P. A study led by Berg to determine the possibility of cloning in $8 \mathrm{~V} 40$ DNA E.coli (intestinal rod) gave a negative reaction. Perhaps the biological threat involved was that experts in the field of cell biology, who were studying changes in the mouse cell induced by the $8 \mathrm{~V} 40$ virus at the time, R. Pollon was particularly concerned. According to him, bacteria containing the $8 \mathrm{~V} 40$ virus can become vectors that spread human cancer. Rekombinant to solve the restriction of the DNA related research in 1975 Aksilomar (Kaliforya USA) at 17 of the country related to molecular biology researchers gathered DNA cloning eksperementlarni only using the methods of genetic test can not live outside the agreed level of weakened organisms o'tkaazish. Most of the above mentioned moral issues, philosophers, biologists and medics senntyabrda in 1974 under the auspices of UNESCO in Paris ( round) were discussed. Human organ transplantation, human mortality ( registration of transplant organ donor death ), artificial termination of pregnancy, euthanasia (medical deprivation of patients with chronic diseases ) and their spiritual aspects The implementation of genetic changes in the context of the development of science and technology to change the biological basis was the focus of the conference participants on esxotoxicology and environmental protection and other issues.

\section{Conclusion}

In conclusion, the family is, in any case, a fortress built by the masters of the family, which should not be demolished. Marriage is the religious and moral value that leads to this fortress. Respect for these values depends on the people in the society. The use of scientific achievements is necessary at all times, only when these values are highly valued, euthanasia, cloning are legally regulated in all countries and moral standards are developed for it, secular and religious values are equal on two scales.

\section{References}

1. Tishchnko P, D. What is auto-efthanasia. Humanitarian examination of man. Moscow.1992.№6-P.35

2. Mukhamedova Z.M .Bioethics. Tashkent: University. 2006. -P.77

3. Arokov V.I. Medical Law Questions and Answers. M: Prior 2001.- P.208.

4 Mukhammedova .Z. Bioethics.T. University.2006.-P.81

5 Fut.F. Euthanasia. Philosophical sciences: M. 1990.№6. P.62-80 
6. Reychels DJ. Active and passive euthanasia. Ethical thought': scientific - journalistic readings. M. 1990.-P. 205-211

7. Potter.B. Bioethics. Bridge to the future. - Kiev. 2002.-P 42

8. Shermukhamedova N.A. Current issues of science in the XXI century. Philosophy and science methodology. T. University.2005. -P. 195.

9. Wood KL Today the sheep. // Ntwsweek. March 10. 1997.- P.48.

10. Wood ward KL Todat the sheep. // Newsweek. March 10. 1997.- P . 48.

11. Bioorganic chemical on the threshold of the new millennium .// Bulletin of the Academy of Rossiyskoy Nauka. 1999.T. 69.№4. -P.295

12. Essay Journal. Physics. Chemistry. Biology-biotenology.-Moscow. 1985.№10. P.39.

13 .Shrayder.Yu.A. Ethics. - M: 1998.S - 244-248. 